\title{
KINERJA PERTUMBUHAN DAN EFISIENSI PAKAN IKAN Tor tambroides YANG DIBERI PAKAN KOMERSIAL DENGAN KANDUNGAN PROTEIN BERBEDA
}

\author{
Deni Radona*, Jojo Subagja, dan Irin Iriana Kusmini \\ Balai Riset Perikanan Budidaya Air Tawar dan Penyuluhan Perikanan \\ (Naskah diterima: 20 Maret 2017; Revisi final: 9 Juni 2017; Disetujui publikasi: 9 Juni 2017)
}

\begin{abstract}
ABSTRAK
Protein merupakan nutrien yang sangat berperan dalam pertumbuhan ikan. Penelitian ini bertujuan mengetahui kebutuhan protein optimal untuk pertumbuhan ikan Tor tambroides dan pengaruh kandungan protein pakan terhadap efisiensi pakannya. Benih ikan Tor yang digunakan berukuran panjang $(1,5 \pm 0,1$ $\mathrm{cm})$ dan bobot $(0,08 \pm 0,01 \mathrm{~g})$. Benih ikan dipelihara dalam akuarium berukuran $40 \mathrm{~cm} \times 30 \mathrm{~cm} \times 30 \mathrm{~cm}$ dengan ketinggian air $20 \mathrm{~cm}$ sebanyak 50 ekor. Selama 40 hari pemeliharaan benih ikan diberi pakan komersil berupa crumble dengan kandungan protein, (A) $25 \%$ (B) $35 \%$ dan (C) $50 \%$ sebanyak $20 \%$ per hari dari total biomassa ikan, pemberian pakan dengan frekuensi tiga kali sehari. Rancangan penelitian menggunakan rancangan acak lengkap dengan tiga perlakuan dan tiga ulangan. Hasil penelitian menunjukkan ikan Tor tambroides yang diberi pakan dengan kandungan protein sebesar 35\% dan 50\% memiliki pertumbuhan panjang, bobot, laju pertumbuhan harian (LPH), biomassa, nisbah konversi pakan $(F C R)$, dan efisiensi pakan yang sama $(P>0,05)$ dan berbeda nyata pada pakan dengan kandungan protein $25 \%(P<0,05)$.
\end{abstract}

KATA KUNCI: Tor tambroides; protein; pertumbuhan; efisiensi; pakan

ABSTRACT: Growth performance and feed efficiency of Thai mahseer fed commercial diets with different protein levels. By: Deni Radona, Jojo Subagja, and Irin Iriana Kusmini

Protein is a nutrient is which plays a major role in the growth of fish. This study was aimed to determine the optimal protein requirement for growing of Thai mahseer and the influence of different protein levels of feed on feed efficiency. The average length and weight of fish used were $1.5 \pm 0.1 \mathrm{~cm}$ and $0.08 \pm 0.01 \mathrm{~g}$. The fish were reared in the aquarium (dimension $=40 \mathrm{~cm} \times 30 \mathrm{~cm} \times 30 \mathrm{~cm}$ filled with $20 \mathrm{~cm}$ of water and the stocking density of each aquarium was 50 individuals. During 40-day reared, seedling fish were fed by commercial crumble with different protein levels, (A) $25 \%$ (B) $35 \%$ and (C) $50 \%$ as much as $20 \%$ of total weight every day with a feeding frequency of three times per day. This experiment was conducted by using completely randomized design (CRD) with three treatments and three replications for each treatment. The results showed that Tor tambroides fed diets with protein levels of 35\%and 50\% was not significantly different on the growth value (length and weight), specific growth rate, biomass, feed conversion ratio $(F C R)$, and feed efficiency $(P>0.05)$ and was significantly different on feed protein levels $25 \%(P<0.05)$.

KEYWORDS: Thai mahseer; protein; growth; efficiency; feed

\section{PENDAHULUAN}

Ikan Tor tambroides merupakan komoditas asli perairan tawar Indonesia yang banyak tersebar di Sumatera, Jawa, dan Kalimantan. Salah satu komoditas lokal yang mempunyai nilai ekonomis tinggi sebagai ikan konsumsi maupun ikan hias (Kiat, 2004). Di Instalasi Penelitian Plasma Nutfah Perikanan Air Tawar

\footnotetext{
\# Korespondensi: Balai Riset Perikanan Budidaya Air Tawar dan Penyuluhan Perikanan

Il. Sempur No. 1, Bogor 16154, Indonesia.

Tel.: + (0251) 8313200

E-mail: deniradona_kkp@yahoo.com
}

Bogor, ikan ini sudah berhasil dibudidayakan pertama kali pada Tahun 2011 secara kawin suntik (Asih et al., 2004). Ikan genus Tor memiliki karakter pertumbuhan yang lambat. Penelitian Radona et al. (2016) melaporkan pada ikan Tor soro dan semah Tor douronensis, memiliki nilai laju pertumbuhan harian (LPH) pada karakter panjang hanya $<1 \%$ dan pada karakter bobot berkisar 2\%3\% Karakter pertumbuhan yang lambat berdampak pada peningkatan kebutuhan pakan.

Dalam mendukung keberhasilan produksi ikan Tor diperlukan salah satu input produksi yaitu pakan. Pakan 
merupakan komponen yang sangat menentukan keberhasilan budidaya. Pemberian nutrien pakan yang tepat akan menghasilkan pertumbuhan dan efisiensi pakan yang optimal. Protein merupakan nutrien yang sangat berperan dalam pertumbuhan karena sebagai komponen terbesar dari daging dan berfungsi sebagai bahan pembentuk jaringan tubuh (Halver \& Hardy, 2002). Beberapa studi penentuan kebutuhan protein pada ikan perairan tawar sudah banyak dilakukan di antaranya pada benih ikan nila Oreochromis niloticus (Abdel-Tawwab et al., 2010), benih ikan patin Pangasianodon hypophthalmus (Poernomo, 2015), benih ikan baung Hemibagrus nemurus (Suhenda et al., 2010), benih grass carp Ctenopharyngodon idella (Xu et al., 2016; Jin et al., 2015), ikan snakehead Channa (Zhang et al., 2017). Hasil dari penelitian menunjukkan adanya pengaruh kandungan protein pakan terhadap pertumbuhan ikan dan efisiensi pakannya.

Kandungan protein pakan pada ikan Tor tambroides yang tepat diharapkan dapat meningkatkan pertumbuhan dan produktivitasnya. Penelitian ini bertujuan untuk mengetahui kebutuhan protein optimal untuk pertumbuhan ikan Tor tambroides dan pengaruh kandungan protein pakan terhadap efisiensi pakannya.

\section{BAHAN DAN METODE}

Penelitian dilakukan di Instalasi Penelitian Plasma Nutfah Perikanan Air Tawar, Balai Penelitian dan Pengembangan Budidaya Air Tawar Bogor. Penelitian dilakukan secara eksperimental menggunakan rancangan acak lengkap dengan tiga perlakuan dan tiga ulangan. Benih ikan Tor tambroides yang digunakan berukuran panjang $1,5 \pm 0,1 \mathrm{~cm}$ dan bobot $0,08 \pm$ $0,01 \mathrm{~g}$; merupakan hasil pemijahan secara induksi hormon dari induk hasil tangkapan alam yang diadaptasi selama empat tahun di kolam penelitian. Pemeliharaan dilakukan dalam akuarium berukuran $40 \mathrm{~cm} \times 30 \mathrm{~cm} \times$ $30 \mathrm{~cm}$ dengan ketinggian air $20 \mathrm{~cm}$. Setiap akuarium diberi sistem aerasi dengan intensitas kecepatan yang sama dan ditebar benih sebanyak 50 ekor. Kualitas air pada akuarium dikontrol dengan penyiponan dan pergantian air sebanyak 30\%50\% setiap tiga hari. Selama 40 hari pemeliharaan benih ikan diberi pakan komersil (Polaris aqua) berupa crumble dengan kandungan protein yang berbeda, yaitu (A) $25 \%$ (B) $35 \%$ dan (C) $50 \%$ sebanyak $20 \%$ per hari dari total biomassa ikan. Pakan diberikan dengan frekuensi tiga kali sehari (pagi, siang, dan sore). Komposisi pakan komersial terdiri atas serat $(2,2 \%)$, lemak $(16,0 \%$, dan abu $(6,0 \%)$.

Pengamatan pertumbuhan dan sintasan dilakukan setiap 10 hari dengan mengukur panjang dan bobot individu sebanyak $20 \%$ dari total populasi per akuarium. Pengamatan laju pertumbuhan harian (LPH), biomassa, nisbah konversi pakan (FCR), dan efisiensi pakan dilakukan pada akhir penelitian. Paramater pertumbuhan, sintasan, $\mathrm{LPH}$, dan biomassa dihitung berdasarkan rumus menurut Effendie (2002) sedangkan FCR dan efisiensi pakan menurut Takeuchi (1988).

\section{Nisbah Konversi Pakan}

$$
F C R=\frac{F}{(W t+D)-W_{0}}
$$

di mana:

$\mathrm{FCR}=$ nisbah konversi pakan

$\mathrm{F}=$ bobot pakan yang diberikan $(\mathrm{g})$

$\mathrm{Wt}=$ bobotikan pada akhir penelitian $(\mathrm{g})$

$\mathrm{D}=$ bobotikan yang mati $(\mathrm{g})$

$W_{0}=$ bobotikan pada awal penelitian $(\mathrm{g})$

Efisiensi Pakan

$$
\mathrm{FE}=\frac{(\mathrm{Wt}+\mathrm{D})-\mathrm{Wo}_{0}}{\mathrm{~F}} \times 100
$$

$$
\begin{array}{ll}
\text { di mana: } & \\
\mathrm{FE}= & \text { efisiensi pakan }(\% \\
\mathrm{F}= & \text { bobot pakan yang di berikan }(\mathrm{g}) \\
\mathrm{Wt}= & \text { bobot ikan pada akhir penelitian }(\mathrm{g}) \\
\mathrm{D}= & \text { bobot ikan yang mati }(\mathrm{g}) \\
\mathrm{W}= & \text { bobot ikan pada awal penelitian }(\mathrm{g})
\end{array}
$$

Sebagai data pendukung dilakukan pengamatan kondisi air di akuarium pada hari ke-2 pemeliharaan (sehari sebelum penyiponan) dengan selang tiga jam selama 24 jam. Parameter suhu $\left({ }^{\circ} \mathrm{C}\right)$, pH, dan oksigen terlarut (mg/L) diukur langsung saat pengamatan menggunakan Multi Parameter Water Quality M eter EC 900 dengan ketelitian 0,1. Alkalinitas (mg/L), nitrat $(\mathrm{mg} / \mathrm{L})$, nitrit $(\mathrm{mg} / \mathrm{L})$, dan TOM (Total organic matter) (mg/L) diamati di laboratorium Uji Balai Penelitian dan Pengembangan Budidaya Air Tawar, Bogor yang sudah terakreditasi ISO 17025:2008 (LP-711 IDN).

Data yang diperoleh kemudian ditabulasi dan dianalisis secara statistik menggunakan bantuan program SPSS versi 18 . Uji banding keragaman pertumbuhan mutlak, sintasan, LPH, biomassa, FCR, dan efisiensi pakan dianalisis dengan analisis varian (ANOVA) pada selang kepercayaan 95\%dan uji lanjut Duncan.

\section{HASIL DAN BAHASAN}

\section{Kinerja Pertumbuhan}

Hasil penelitian selama 40 hari menunjukkan bahwa ikan Tor tambroides yang diberi pakan dengan kandungan protein $35 \%$ dan $50 \%$ memiliki pertumbuhan 
panjang, bobot, dan LPH yang tidak berbeda nyata $(P>0,05)$ namun berbeda $(P<0,05)$ dengan kandungan protein $25 \%$ Nilai pertumbuhan panjang, bobot, dan LPH ikan Tor tambroides selama penelitian disajikan pada Tabel 1 dan pertumbuhan setiap 10 hari pemeliharaan ditampilkan pada Gambar 1 dan 2.

Protein merupakan nutrien yang sangat berperan dalam pertumbuhan ikan, karena protein sebagai komponen terbesar dari daging dan berfungsi sebagai bahan pembentuk jaringan tubuh (Halver \& Hardy, 2002). Pakan ikan dengan kandungan protein berbeda dapat memberikan pengaruh pada pertumbuhan ikan Tor tambroides. Pada grafik (Gambar 1 dan 2) terlihat pola pertumbuhan yang meningkat setiap 10 hari pengamatan. Grafik yang dihasilkan menunjukkan kurva berbentuk sigmoid. Pemberian pakan komersil dengan protein $35 \%$ dan $50 \%$ memberikan nilai pertumbuhan panjang dan bobot yang optimal, serta dapat meningkatkan nilai LPH sekitar 1\%pada karakter bobot. Secara statistik nilai pertumbuhan yang dihasilkan menunjukkan perbedaan secara nyata $(P<0,05)$ dengan kandungan protein sebesar $25 \%$
(Tabel 1), hal ini mengindikasikan bahwa kebutuhan protein (35\%50\% yang terkandung dalam pakan sudah optimal dan dapat termanfaatkan secara baik untuk proses pertumbuhan ikan Tor. Ikan genus Tor termasuk dalam kelompok ikan omnivora. Tacon (1987) menyatakan bahwa kebutuhan protein pada ikan-ikan berjenis omnivora berkisar 35\%45\%

Kebutuhan protein pada ikan bervariatif tergantung spesiesnya. Beberapa penelitian melaporkan bahwa kebutuhan protein pada ikan kerapu Epinephelus sebesar 45\%53\%(Jiang et al., 2015; 2016), ikan grass carp Ctenopharyngodon idella sebesar $20 \% 45 \%$ (lin et al., 2015), ikan nila Oreochromis niloticus sebesar 35\%45\%(Abdel Tawwab et al., 2010) dan ikan snout bream Megalobrama amblycephala sebesar 35\% (Li et al., 2010). Abdel-Tawwab et al. (2010) dan Arnason et al. (2010) menyatakan bahwa kebutuhan protein akan menurun dengan meningkatnya bobot dan usia ikan.

Kandungan protein yang rendah pada pakan umumnya memiliki kandungan total energi yang rendah. Ikan dalam aktivitas dan proses metabolisme

Tabel 1. Pertumbuhan panjang, bobot, dan LPH ikan Tor tambroides selama 40 hari penelitian

Table 1. Length gain, weight gain, and specific growth rate of Thai mahseer for 40 days of experiment

\begin{tabular}{lccc}
\hline \multicolumn{1}{c}{$\begin{array}{c}\text { Parameter pertumbuhan } \\
\text { Growth parameters }\end{array}$} & \multicolumn{3}{c}{ Kandungan protein pakan (Protein levels) } \\
\cline { 2 - 4 } & $\mathbf{2 5 \%}$ & $\mathbf{3 5 \%}$ & $\mathbf{5 0 \%}$ \\
\hline $\begin{array}{l}\text { Panjang awal } \\
\text { Initial length (cm) }\end{array}$ & $1.48 \pm 0.01$ & $1.49 \pm 0.02$ & $1.47 \pm 0.02$ \\
$\begin{array}{l}\text { Bobot awal } \\
\text { Initial body weight (g) }\end{array}$ & $0.08 \pm 0.01$ & $0.08 \pm 0.02$ & $0.08 \pm 0.02$ \\
$\begin{array}{l}\text { Panjang akhir } \\
\text { Final length (cm) }\end{array}$ & $2.05 \pm 0.02$ & $2.33 \pm 0.05$ & $2.40 \pm 0.05$ \\
$\begin{array}{l}\text { Bobot akhir } \\
\text { Final body weight (g) }\end{array}$ & $0.22 \pm 0.02$ & $0.35 \pm 0.01$ & $0.38 \pm 0.02$ \\
$\begin{array}{l}\text { Pertumbuhan panjang } \\
\text { Length gain (cm) }\end{array}$ & $0.57 \pm 0.01^{\mathrm{a}}$ & $0.85 \pm 0.06^{\mathrm{b}}$ & $0.94 \pm 0.05^{\mathrm{b}}$ \\
$\begin{array}{l}\text { Pertumbuhan bobot (g) } \\
\text { Weight gain } \\
\text { LPH panjang (\%hari) }\end{array}$ & $0.14 \pm 0.01^{\mathrm{a}}$ & $0.27 \pm 0.01^{\mathrm{b}}$ & $0.30 \pm 0.02^{\mathrm{b}}$ \\
$\begin{array}{l}\text { Specific growth rate of length (\%/day) } \\
\text { LPH bobot (\%/hari) }\end{array}$ & $0.81 \pm 0.01^{\mathrm{a}}$ & $1.13 \pm 0.07^{\mathrm{b}}$ & $1.23 \pm 0.06^{\mathrm{b}}$ \\
$\begin{array}{l}\text { Specific growth rate of weight (\%/day) } \\
\text { Ker }\end{array}$ & $2.42 \pm 0.10^{\mathrm{a}}$ & $3.61 \pm 0.06^{\mathrm{b}}$ & $3.79 \pm 0.24^{\mathrm{b}}$ \\
\hline
\end{tabular}

Keterangan: Angka yang diikuti huruf yang sama pada lajur yang sama menunjukkan tidak adanya perbedaan nyata menurut Uji Duncan $(P>0,05)$

Remarks: Numbers followed by the same superscript letter in the same row indicates no significantly difference 


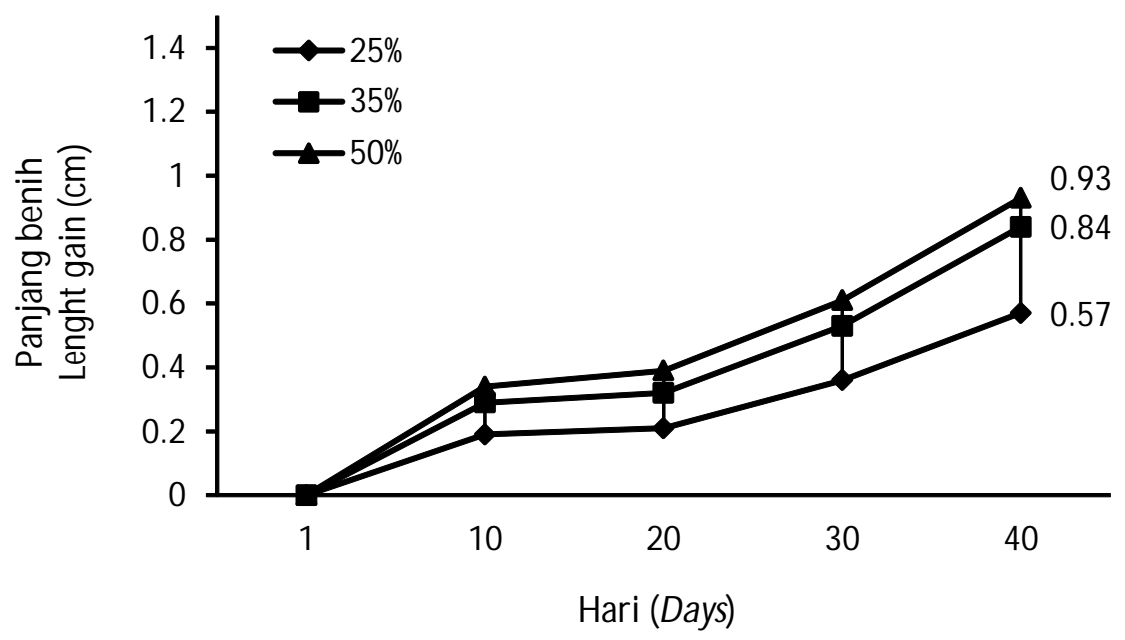

Gambar 1. Pertumbuhan panjang benih ikan Tor tambroides selama 40 hari pemeliharaan.

Figure 1. Length gain of Thai mahseer seedling for 40 days rearing.

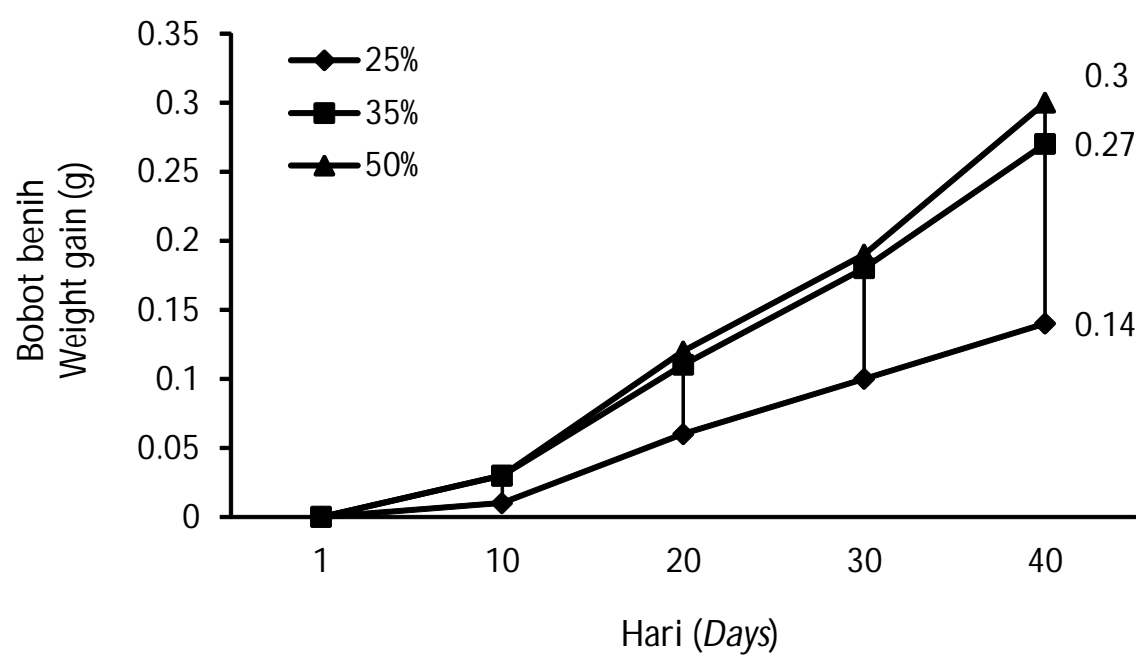

Gambar 2. Pertumbuhan bobot benih ikan Tor tambroides selama 40 hari pemeliharaan.

Figure 2. Weight gain of Thai mahseer seedling for 40 days rearing.

untuk memenuhi kebutuhan energi menggunakan protein, sehingga jumlah protein yang dimanfaatkan bagi pertumbuhan jaringan struktural akan berkurang dan akibatnya pertumbuhan menjadi lambat (Kim \& Lee, 2005; Halver \& Hardy, 2002). Selain itu, protein yang berlebihan juga tidak akan efektif karena tidak akan termanfaatkan dan protein termetabolisme sebagai energi (NRC, 2011; Hu et al., 2008).

\section{Sintasan}

Hasil pengamatan sintasan benih ikan Tor tambroides selama 40 hari penelitian disajikan pada Gambar 3.
Nilai sintasan setiap perlakuan relatif tinggi dan secara statistik nilai sintasan yang diperoleh selama penelitian menunjukkan tidak berbeda nyata $(P>0,05)$ antar perlakuan pemberian pakan dengan kandungan protein $25 \% 35 \%$ dan $50 \%$

Beberapa penelitian sebelumnya melaporkan hal yang sama, kandungan protein pada pakan tidak memengaruhi nilai sintasan ikan, seperti pada ikan grass carp (Jin et al., 2015), ikan nila (Abdel-Tawwab et al., 2010), kerapu hibrid (Jiang et al., 2016; Rahimnejad et al., 2015), dan teripang (Bai et al., 2016). Kandungan protein yang optimal dalam pakan akan meningkatkan 


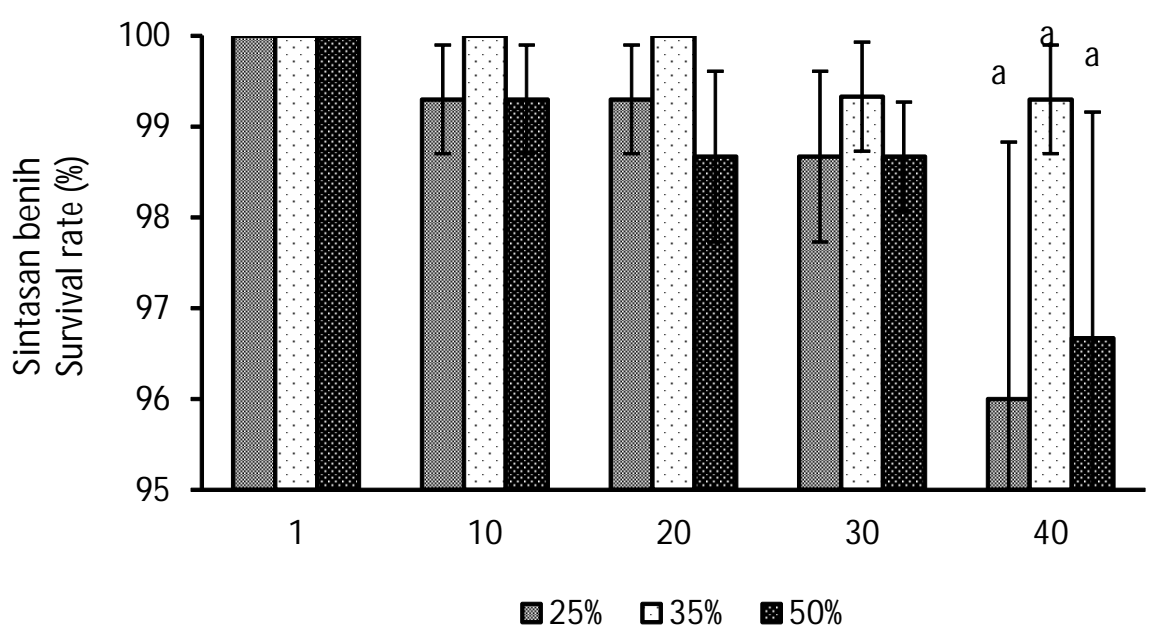

Hari (Days)

Gambar 3. Sintasan benih ikan Tor tambroides selama 40 hari pemeliharaan.

Figure 3. Survival rate of Thai mahseer seedling for 40 days rearing.

fungsi imun dalam insang ikan sehingga ketahanan tubuh ikan menjadi optimal (Xu et al., 2016).

\section{Biomassa, FCR, dan Efisiensi Pakan}

Hasil pengamatan biomassa, FCR, dan efisiensi pakan benih ikan Tor tambroides selama 40 hari penelitian disajikan pada Tabel 2.

Hasil penelitian menunjukkan nilai biomassa, FCR, dan efisiensi pakan pada kandungan protein sebesar
$35 \%$ dan $50 \%$ memberikan nilai yang optimum dan tidak berbeda nyata $(P>0,05)$ namun berbeda dengan kandungan protein $25 \%$ Biomassa merupakan bobot semua benih yang masih hidup pada akhir pemeliharaan. Nilai biomassa sangat dipengaruhi oleh nilai sintasan populasi sedangkan efisensi pakan dipengaruhi oleh kandungan protein pakan. Efisiensi pakan merupakan proporsi pertambahan biomassa ikan dengan jumlah pakan yang dikonsumsi ikan (Giri et al., 2007). Tingginya nilai efisiensi pakan yang

Tabel 2. Nilai biomassa, FCR, dan efisiensi pakan benih ikan Tor tambroides Table 2. Biomass value, FCR, and feed efficiency of Thai mahseer seedling

\begin{tabular}{lccc}
\hline \multirow{2}{*}{ Parameter } & \multicolumn{3}{c}{ Kandungan protein (Protein levels) } \\
\cline { 2 - 4 } & $\mathbf{2 5 \%}$ & $\mathbf{3 5 \%}$ & $\mathbf{5 0 \%}$ \\
\hline $\begin{array}{l}\text { Biomassa awal } \\
\text { Initial biomass }(\mathrm{g})\end{array}$ & $4.17 \pm 0.24$ & $4.17 \pm 0.24$ & $4.17 \pm 0.24$ \\
$\begin{array}{l}\text { Biomassa akhir } \\
\text { Final biomass (g) }\end{array}$ & $10.70 \pm 0.63$ & $17.58 \pm 0.72$ & $18.49 \pm 0.74$ \\
$\begin{array}{l}\text { Pertambahan biomassa } \\
\text { Biomass gain (g) }\end{array}$ & $6.53 \pm 0.42^{\mathrm{a}}$ & $13.41 \pm 0.52^{\mathrm{b}}$ & $14.33 \pm 0.98^{\mathrm{b}}$ \\
$\begin{array}{l}\text { Nisbah konversi pakan } \\
\text { Feed convertion ratio (FCR) }\end{array}$ & $7.46 \pm 0.09^{\mathrm{a}}$ & $4.76 \pm 0.17^{\mathrm{b}}$ & $4.58 \pm 0.10^{\mathrm{b}}$ \\
$\begin{array}{l}\text { Efisiensi pakan } \\
\text { Feed effeciency (\%) }\end{array}$ & $13.41 \pm 0.16^{\mathrm{a}}$ & $21.03 \pm 0.75^{\mathrm{b}}$ & $21.85 \pm 0.48^{\mathrm{b}}$ \\
\hline
\end{tabular}

Keterangan: Angka yang diikuti huruf yang sama pada lajur yang sama menunjukkan tidak adanya perbedaan nyata menurut Uji Duncan $(P>0,05)$

Remarks: Numbers followed by the same superscript letter in the same row indicates no significant difference 
diperoleh pada benih ikan Tor tambroides yang diberi pakan dengan protein $35 \%$ dan $50 \%$ menunjukkan kualitas pakan yang lebih baik sehingga ikan dapat memanfaatkan secara optimal.

Nilai FCR menunjukkan pemanfaatan nutrien pakan oleh ikan, semakin rendah nilai FCR yang dihasilkan menunjukkan penggunaan pakan tersebut semakin efisien. Nilai FCR pada ikan Tor tambroides yang diberi pakan dengan kandungan protein $35 \%(4,7)$ dan $50 \%$ $(4,5)$ ini menunjukkan bahwaikan dapat memanfaatkan pakan secara efisien.

\section{Kualitas Air}

Hasil pengukuran kualitas air selama penelitian disajikan pada Tabel 3.

Kualitas air merupakan salah satu faktor pendukung yang dapat menunjang pertumbuhan dan sintasan pada ikan. Suhu, oksigen terlarut, dan pH dapat berpengaruh terhadap laju metabolisme tubuh di mana dapat meningkatkan aktivitas metabolisme dan dapat meningkatkan nafsu makan ikan (Mallya, 2007; Zonneveld et al., 1991). Secara umum nilai kualitas air (Tabel 3) yang didapatkan masih dalam batas normal untuk proses pertumbuhan dan sintasan padaikan genus Tor (Subagja \& Radona, 2017; Radona et al., 2016; 2015; Subagja et al., 2013). Variabel kualitas air yang terukur dari setiap perlakuan pemberian pakan dengan kandungan protein yang berbeda tidak menunjukkan perbedaan nilai secara signifikan karena penelitian ini dilakukan secara terkontrol di hatchery.

\section{KESIMPULAN}

Pakan dengan kandungan protein 35\%50\%dapat efektif mendukung pertumbuhan dan meningkatkan nilai efisiensi pakan pada ikan Tor tambroides.

\section{UCAPAN TERIMA KASIH}

Ucapan terima kasih diberikan kepada Bapak Sudarmaji dan Heppy Aprilistanto atas bantuan teknis yang diberikan.

\section{DAFTAR ACUAN}

Abdel-Tawwab, M., Ahmad, M., Khattab, Y.A.E., \& Shalaby, A.D.E. (2010). Effect of dietary protein level, initial body weight, and their interaction on the growth, feed utilization, and physiological alterations of nile tilapia, Oreochromis niloticus. Aquaculture, 298, 267-274.

Arnason, J., Bjornsdottir, R., Arnarsson, I., Arnadottir, G.S., \& Thorarensen, H. (2010). Protein requirements of atlantic cod Gadus morhua L. Aquaculture, 41, 385-393.

Asih, S., Subagja, J., Winarlin, \& Widiyati, A. (2004). Penguasaan teknik pembenihan dan pembesaran ikan batak: peningkatan kualitas telur melalui perlakuan hormonal pada penyuntikan awal dalam berbagai dosis dan selang waktu berbeda. Laporan Hasil Penelitian Balai Riset Perikanan Budidaya Air Tawar, 314-323 hlm.

Bai, Y., Zhang, L., Xia, S., Liu, S., Ru, X., Xu, Q., Zhang, T., \& Yang, H. (2016). Effects of dietary protein levels on the growth, energy budget and physiological and immunological performance of green, white and purple color morphs of sea cucumber, Apostichopus japonicus. Aquaculture, 450, 375-382.

Effendie, M.I. (2002). Biologi perikanan. Yogyakarta: Yayasan Pustaka Nusatama, $163 \mathrm{hlm}$.

Giri, N.A., Suwirya, K., Pithasari, A.I., \& Marzuqi, M. (2007). Pengaruh kandungan protein pakan terhadap pertumbuhan dan efisiensi pakan benih kakap merah Lutjanus argentimaculatus. Journal Fish Science, 9(1), 55-62.

Tabel 3. Nilai kualitas air selama penelitian

Table 3. The value of water quality in the aquarium during the experiment

\begin{tabular}{lc}
\hline \multicolumn{1}{c}{$\begin{array}{c}\text { Variabel (Kualitas air) } \\
\text { Variable (Water quality) }\end{array}$} & $\begin{array}{c}\text { Kisaran } \\
\text { Range }\end{array}$ \\
\hline Suhu (Temperature) $\left({ }^{\circ} \mathrm{C}\right)$ & $22.1-27.3$ \\
pH & $5.8-7.4$ \\
Oksigen terlarut (Dissolved oxygen) (mg/L) & $5.1-7.5$ \\
Alkalinitas (Alkalinity) (mg/L) & $84.7-86.8$ \\
Nitrit (Nitrite) (mg/L) & $0.016-0.022$ \\
Nitrat (Nitrate) (mg/L) & $0.71-1.40$ \\
TOM (Total organic matter) & $5.01-9.78$ \\
\hline
\end{tabular}


Halver, J.E. \& Hardy, R.W. (2002). Fish nutrition. Third edition. London: Academic Press, 823 pp.

Hu, Y., Tan, B.P., Mai, K.S., Zheng, S., \& Cheng, K. (2008). Growth and body composition of juvenile white shrimp, Litopenaeus vannamei, fed different ratios of dietary protein to energy. Aquaculture Nutrition, 14, 499-506.

Jiang, S., Luo, Y., Wu, M., Lu, S., Jin, Z., \& Yao, W. (2016). Optimal dietary protein level and protein to energy ratio for hybrid grouper Epinephelus fuscoguttatus @ \& X Epinephelus lanceolatus B\& juveniles. Aquaculture, 465, 28-36.

Jiang, S.T., Wu, X.Y., Li, W.F., Wu, M.J., Luo, Y., Lu, S.D., \& Lin, H.R. (2015). Effects of dietary protein and lipid levels on growth, feed utilization, body and plasma biochemical compositions of hybrid grouper Epinephelus lanceolatus $B \& \times$ Epinephelus fuscoguttatus @ \& juveniles. Aquaculture, 446, 148-155.

Jin, Y., Tian, L., Xie, S., Guo, D., Yang, H., Liang, G., \& Liu, Y. (2015). Interactions between dietary protein levels, growth performance, feed utilization, gene expression and metabolic products in juvenile grass carp Ctenopharyngodon idella. Aquaculture, 437, 75-83.

Kiat, Ng Chi. (2004). The kings of the rivers Mahseer in Malayan and the region. Inter Sea Fishery, Selangor. Malaysia, $170 \mathrm{pp}$.

Kim, L.E. \& Lee, S.M. (2005). Effects of the dietary protein and lipid levels on growth and body composition of bagrid catfish, Pseudobagrus fulvidraco. Aquaculture, 243, 323-329.

Li, X., Liu, W., Jiang, Y., Zhu, H., \& Ge, X. (2010). Effects of dietary protein and lipid levels in practical diets on growth performance and body composition of blunt snout bream Megalobrama amblycephala fingerlings. Aquaculture, 303, 65-70.

Mallya, Y.J. (2007). The effects of dissolved oxygen on fish growth in aquaculture. UNU-Fisheries Training Programme, $30 \mathrm{pp}$.

National Research Council [NRC]. (2011). Nutrient requirements of fish and shrimp. Washington, National Academies Press, 376 pp.

Poernomo, N. (2015). Kinerja pertumbuhan dan kualitas daging ikan patin Pangasianodon hypophthalmus yang diberi pakan komersial dengan kadar protein berbeda. Tesis. Institut Pertanian Bogor. Bogor, 35 $\mathrm{hlm}$.

Radona, D., Subagja, J., Kusmini, I.I., \& Gustiano, R. (2016). Nilai heterosis dan peranan induk pada karakter pertumbuhan hasil persilangan interspesifik Tor soro dan Tor douronensis. Berita Biologi, 15(2), 107-112.

Radona, D., Subagja, J., \& Arifin, O.Z. (2015). Karakterisasi reproduksi induk dan pertumbuhan benih ikan tor hasil persilangan Tor soro dan Tor douronensis secara resiprokal. J. Ris. Akuakultur, 10(3), 335-343.

Rahimnejad, S., Bang, I.C., Park, J., Sade, A., Choi, J., $\&$ Lee, S. (2015). Effects of dietary protein and lipid levels on growth performance, feed utilization and body composition of juvenile hybrid grouper, Epinephelus fuscoguttatus $\times \mathrm{E}$. Lanceolatus. Aquaculture, 446, 283-289.

Subagja, J. \& Radona, D. (2017). Produktivitas ikan semah Tor douronensis Valenciennes, 1842 pascalarva pada lingkungan ex situ dengan kepadatan berbeda. J. Ris. Akuakultur, 12(1), 4148.

Subagja, J., Radona, D., Cahyanti, W., \& Asih, S. (2013). Pembenihan ikan semah Tor douronensis. Val. 1842. Laporan teknis penelitian APBN BPPBAT Bogor. Unpublished.

Suhenda, N., Samsudin, R., \& Nugroho, E. (2010). Pertumbuhan benih ikan baung Hemibagrus nemurus dalam keramba jaring apung yang diberi pakan buatan dengan kadar protein berbeda. Jurnal Iktiologi Indonesia, 10(1), 65-71.

Tacon, A.G.I. (1987). The nutrition and feeding of farm fish and shrimp a training manual. FAO Brasilia. Brazil, 117 pp.

Takeuchi, T. (1988). Fish nutrition and mariculture. Departement of Aquatic Bioscience, Tokyo University of Fisheries. Japan, $233 \mathrm{pp}$.

Xu, J., Feng, L., Jiang, W., Wu, P., Liu, Y., Jiang, J., Kuang, S., Tang, L., Tang, W., Zhang, Y., \& Zhou, $X$. (2016). Effects of dietary protein levels on the disease resistance, immune function and physical barrier function in the gill of grass carp Ctenopharyngodon idella after challenged with Flavobacterium columnare. Fish and Shellfish Immunology, 57, 1-16.

Zhang, Y., Sun, Z., Wang, A., Ye, C., \& Zhu, X. (2017). Effects of dietary protein and lipid levels on growth, body and plasma biochemical composition and selective gene expression in liver of hybrid snakehead Channa maculata @ \& $\times$ Channa argus $B \&$ fingerlings. Aquaculture, 468, 1-9.

Zonneveld, N., Huisman, E.A., \& Boon, J.H. (1991). Prinsip-prinsip budidaya ikan. Jakarta: Gramedia Pustaka Utama, 317 hlm. 